\title{
MUTUAL SPECIALISATION, SEAPORTS AND THE GEOGRAPHY OF AUTOMOBILE IMPORTS
}

\author{
PETER V. HALL \\ Department of Geography, University of Waterloo, 200 University Avenue West, Waterloo, Ontario, N2L 3G1, \\ Canada. E-mail: pvhall@fes.uwaterloo.ca
}

Received: September 2003

\begin{abstract}
This paper argues for a more actor-centred approach in freight transportation studies, one that includes freight shippers and public authorities, as well as carriers, and that pays close attention to the relationships between these actors. One advantage of this approach is that it focuses on the conditions under which global logistics flows may become relatively fixed in particular localities. The perspective is illustrated through a discussion of the geography of port usage by importers of automobiles to the US since $\mathbf{1 9 8 0}$. The need to secure space at or near marine terminals for vehicle processing activities is a driving factor in port selection. While the overall trade in automobiles has not become concentrated in fewer ports over the last 20 years, individual firms are concentrating the bulk of their import operations in fewer ports. This mutual specialisation involves a process of interpenetration between actors that is only visible in a disaggregated analysis.
\end{abstract}

Key words: Logistics, United States, transport geography, seaports, automobiles

\section{INTRODUCTION}

It is now widely accepted that globalisation, the 'accelerated circulation of people, commodities, capital, money, identities and image through global space' (Brenner 1999, p. 431), has varied and differential implications for people and places. Geographers have debated the scale at which to understand these processes, in particular, the relative importance of the global and regional scales (Storper 1997; Cox 1997; Lipietz 1993). Freight transportation studies have tended to emphasise the global dimensions of the debate, focusing inter alia on the rise of containerisation and intermodalism, hub-and-spoke distribution systems, transportation industry consolidations and the role information technology. Seaports have been portrayed as structurally disadvantaged nodes in the global freight transportation system (Slack 1993; Heaver 1995). The system-wide approach to studying logistics finds support in meta-analyses of the global economy as an interregional network of flows (Castells 1996). In essence, the global approach reads off the fortunes of particular places from their relative position in the larger system.

In stressing the importance of the positionality within a larger system, the global approach ignores the central paradox that the users of international freight transport require a firmspecific 'fix' in the regions through which they route their products (Harvey 1982). In so doing, freight logistics studies may err in implicitly overestimating the relatively mobility of capital, while underestimating the multiple and interrelated ways in which specific formations of capital rely on structures, resources and relationships that are relatively immobile and durable (Storper and Walker 1989; Cox 1995; Dicken, 2003). These factors range from internal firm organisational structures such as branch offices that may acquire a measure of autonomy, to relationships with suppliers and service providers 
that may involve long-term contractual arrangements to secure the substantial investments in fixed capital.

This paper addresses only one of the aspects of fixity, namely the fact that some shippers may find it desirable to store, process or re-package commodities at or near key nodes in logistics networks. For this reason they have to secure and sustain relationships with other actors exercising control at these nodes. For example, when a berth is occupied another ship cannot call there and when a terminal is used for handling one type of commodity it may not be available for handling another. In other words, users of key nodes within logistics networks face a prior requirement for certainty; they need to know that the infrastructure services will be available when needed and even when other things change. Commodity flows must thus be understood as the outcome of the strategic actions of firms seeking such certainty in logistics movements, mediated of course, by the strategic actions of others. The global approach downplays such considerations, ignoring the relationships and practices that arise between individual firms and local agents at such nodes, and that in turn organise and shape the global flows of commodities.

The commodity discussed here are new, fully assembled automobiles. The nodes addressed here are seaports. In the United States, almost all seaports are governed by public authorities created by state and/or local governments (Olson 1992; Sherman 2002). I focus on the trade in automobiles because this allows me to identify the role of shippers (cargo owners), and their relationships with port authorities more clearly. Like steamship lines that require on-dock space to handle their cargo and neardock space to fill/empty/repair/store containers, shippers of automobiles require land at or near the waterfront to deal with "port processing'. This involves some or all of the following functions: paperwork and customs clearance, cleaning and minor repairs, accessorisation and customisation, storage and an efficient connection to landside transportation. Since the early 1980 s, the congestion in the major container ports, and the race to construct container facilities in ports aspiring to become major container ports, has put pressure on other cargo-handling (and non-cargo related) activities. In some cases, automobile processing operations have been displaced to smaller ports, and there are now several niche ports dedicated to handling automobile imports. At the same time, the overall level of imports to the United States has declined with the rise of 'transplant' production by foreign automobile assemblers.

However, the resulting spatial reorganisation has been highly uneven; to understand the resulting geography we have to understand the different ways in which the importers organise their logistics operations, and the consequences of these organisational differences for the relationships between importers and port authorities. Building from a descriptive statistical analysis of the geography of port usage by automobile importers to the US since 1980, I show that there is an actor-specific process of geographic concentration. While the overall trade in automobiles has not become concentrated in fewer ports over the last 20 years, individual firms have concentrated the bulk of their import operations in fewer ports. This mutual specialisation involves a process of interpenetration between the actors that is only visible in a firmand authority-level analysis. In particular, the strategic need by shippers to secure access to terminal space is a crucial factor to understanding which importers use which ports.

The broader argument of this paper is that a more actor-centred theoretical and empirical analysis in freight transportation studies is required. Such an approach includes both freight shippers (cargo owners) and public authorities, in addition to the carriers (shipping lines, railroads, truckers, and so on) that are typically the subjects of transportation geography. The approach pays particular attention to the relationships between these actors, which in turn leads to a deeper understanding of the conditions under which global logistics flows may become relatively fixed in specific places.

\section{WHICH US PORTS HANDLE WHICH AUTOMOBILES?}

Which US ports handle which automobile imports, and how has the geography of this trade changed in the last 20 years? This paper starts with descriptive statistics that show the changing patterns of port usage by specific automobile importers since 1980. This starting 
point highlights an empirical shortcoming in the global approach, namely in a form of sectoral aggregation bias that is related to the way that aggregate flows along networks are treated as homogenous' (Vickerman 1999, p. 47). Data on ocean logistics flows are generally reported only as a unit of volume (i.e. the number of containers or twenty-foot equivalent units) per trade route, seaport or steamship line. Where details on the movement of specific commodities are reported they are organised following the Harmonised System or some other sectorallybased, classification system. Ownership of cargo, the specific identity of the shipper, is almost invariably not reported.

Instead, what is required is a focus on specific actors, be they the carriers or the owners of cargo, and a focus on how actor-specific factors interact with other factors to shape logistics flows. Until relatively recently, statistical evidence to sustain this kind of analysis has been unavailable or extremely costly. However, firmspecific commodity movement data are becoming available; the data source used in this study is the PIERS (Port Import-Export Reporting Service) proprietary database. The PIERS data are captured from individual bills of lading and cargo manifests filed with US Customs.

For this study, data on automobile imports to the US for the month of October in the years 1980, 1990 and 2000 are used. October was chosen because this is one of the busiest months for new automobile imports, and the years 1980, 1990 and 2000 were chosen partly because of the decennial symmetry and partly because each occurred at or near the peak of the import cycle. Including only those records that identified the port of entry and the name of the importing automobile firm, the data provided information on over 6,458 separate import shipments representing 791,617 automobiles.

At the most general level, no particular concentration in the spatial distribution of automobile import handling since 1980 is visible. The share of imports accounted for by the largest automobile ports has decreased, and a pattern of hubs and spokes in automobile distribution has not emerged. This is despite a dramatic decline in the overall number of imports from the mid-1980s to the mid-1990s and dire predictions of port consolidations in the early 1990s (see Ross 1992). Since 1984, East Asian and European automobile manufacturers have opened transplant assembly plants at numerous North American locations. This has reduced the overall volume of new imports - from a high of over four million automobiles and light trucks in 1986, to a low of 1.7 million in 1996 and to just over three million in 2001. This represented about 18 per cent of the total US market, down from 27 per cent in 1987.

Despite the lack of spatial concentration overall, in the period 1980-2000 there have been two kinds of port specialisation within the automobile import trade. The more obvious specialisation can be seen in the emergence of a small number of niche ports that specialise in handling automobiles and perhaps a few other commodities. The more subtle specialisation is the process whereby manufacturers have tended to concentrate the bulk of their operations in fewer ports. Ports have also tended to specialise their automobile handling operations around a smaller number of manufacturers, although some ports have found it possible to continue accommodating several manufacturers. This process of mutual specialisation has resulted in a highly differentiated geography of distribution, one in which the actor-specific factors play a critical role.

Over 30 US (and two Canadian) seaports have been involved in handling imports of new automobiles since 1980, while 15 handled two per cent or more of all imports in 2000 (see Table 1). Ports with a significant presence in the trade hold what are known as 'accounts'; even though the automobile assembler may not have any direct contractual relationship with the port authority, in these ports the firm has a significant presence, with processing, storage and other operations conducted at or near the waterfront.

At the end of the 1990s, the three largest container ports in the United States (New York, Los Angeles and Long Beach), handled significant numbers of automobiles, with the Port of New York and New Jersey being the largest automobile port in the country. This suggests that proximity to market is an important consideration in port usage since these ports have prime locations in the largest metropolitan markets. However, many of the largest automobile ports are outside large metropolitan areas, but with good access to hinterland markets. For example, 
Table 1. Share of foreign auto imports by port.

\begin{tabular}{|c|c|c|c|}
\hline Port & $\begin{array}{c}\text { October } 1980 \\
(\%)\end{array}$ & $\begin{array}{c}\text { October } 1990 \\
(\%)\end{array}$ & $\begin{array}{c}\text { October } 2000 \\
(\%)\end{array}$ \\
\hline New York & 12.8 & 12.4 & 16.4 \\
\hline Jacksonville & 11.2 & 11.3 & 12.6 \\
\hline Portland, OR & 13.5 & 10.1 & 9.8 \\
\hline Long Beach & 8.5 & 9.6 & 7.8 \\
\hline San Diego & -1 & 0.6 & 7.4 \\
\hline Los Angeles & 5.6 & 8.8 & 6.6 \\
\hline Port Hueneme & 0.1 & 3.3 & 6.5 \\
\hline Baltimore & 7.9 & 8.7 & 4.7 \\
\hline Tacoma & 3.8 & 4.8 & 4.5 \\
\hline Brunswick, GA & - & 2.4 & 4.1 \\
\hline Boston & 2.3 & 1.2 & 3.9 \\
\hline Puerto Rico & 1.8 & 2.1 & 2.9 \\
\hline Wilmington, DE & 1.1 & 1.4 & 2.4 \\
\hline Charleston & - & 0.7 & 2.3 \\
\hline Benicia & 6.8 & 5.9 & 2.2 \\
\hline Houston & 7.9 & 4.4 & 1.5 \\
\hline Seattle & 9.8 & 1.6 & 1.4 \\
\hline Vancouver, WA & - & 0.1 & 1.2 \\
\hline New Westminster, BC & - & 1.8 & 0.6 \\
\hline Honolulu & - & - & 0.6 \\
\hline Providence & 1.2 & 1.4 & 0.4 \\
\hline Tampa & - & - & 0.2 \\
\hline Norfolk/Newport News & 0.2 & 0.8 & 0.1 \\
\hline West Palm Beach & - & 0 & 0 \\
\hline Vancouver, BC & - & 0.8 & 0 \\
\hline Savannah & - & 0 & 0 \\
\hline San Francisco & 0.3 & 0.3 & 0 \\
\hline Richmond, CA & 2.3 & 5.3 & 0 \\
\hline Port Everglades & - & 0 & 0 \\
\hline Philadelphia & 0 & - & 0 \\
\hline Oakland & 0 & 0 & 0 \\
\hline Mobile/New Orleans & 0 & - & 0 \\
\hline Miami & 0 & 0 & 0 \\
\hline Galveston & - & 0 & 0 \\
\hline Portsmouth & 2.0 & 0.1 & - \\
\hline Alameda & 0.7 & - & - \\
\hline Other $^{2}$ & 0.2 & 0 & - \\
\hline Total & 100 & 100 & 100 \\
\hline
\end{tabular}

Source: Authors analysis of PIERS Data for October of each year.

Notes: ${ }^{1}$ - indicates no vehicles; 0.0 per cent indicates a less than 0.05 per cent share.

${ }^{2}$ Other Ports include Chester (PA), Chicago, and Albany.

Jacksonville, the second largest automobile port in the country is in the 45th largest metropolitan area, while Portland, the third largest automobile port is in the 22nd largest metropolitan area. ${ }^{1}$ Jacksonville is a gateway to the southeast region, while Portland is a gateway to the Pacific North-West and much of the Mid-West.
Over the last twenty years, the geographic distribution of automobile imports across the ports of the United States has changed in small and subtle ways. Comparing the market shares of individual ports provides some indication of the competition between ports for this cargo. Table 1 shows that there have been 
Table 2. Concentration of automobile imports in US ports.

\begin{tabular}{lccc}
\hline & October 1980 & October 1990 & October 2000 \\
\hline Number of Ports & & & 18 \\
Ports with 1\%+ share of all US imports & 16 & 8 & 7 \\
Ports with 5\% + share of all US imports & 9 & 3 & 2 \\
Ports with 10\%+ share of all US imports & 3 & $33.8 \%$ & $38.7 \%$ \\
Percent of Market & & $52.2 \%$ & $54.0 \%$ \\
Share top 3 ports & $37.6 \%$ & $81.3 \%$ & $80.3 \%$ \\
Share top 5 ports & $55.9 \%$ & $87.9 \%$ & \\
Share top 10 ports & & & \\
\hline
\end{tabular}

Source: Authors analysis of PIERS Data for October of each year.

few significant new entries in the last 20 years at ports such as Port Hueneme (California), San Diego and Brunswick (Georgia). At each of these non-container ports, one or more private vehicle-processing firms established a facility and actively attracted automobile importers to use the port.

For example, at San Diego the US-based transportation services firm, Pasha, opened a vehicle processing operation after losing its terminal lease in the Port of Long Beach to Toyota (Hall 2002). The steamship line that carries the most imported new automobiles to the United States, Wallenius-Wilhelmsen Lines (WWL) has opened automobile processing facilities at Brunswick and Port Hueneme. This is part of a conscious strategy on the part of WWL to maintain market share in the ocean carriage of automobiles. $^{2}$

There have also been few significant exits, most notably at ports such as Richmond (California), Seattle and Houston. In the case of Houston, this is because of the rise of a miniland-bridge from the Southern California ports for imported vehicles. However, it is remarkable how many ports have displayed stability in market share. Ports such as Baltimore, ${ }^{3}$ Portland, Tacoma, Long Beach, Los Angeles, Jacksonville, Boston, New York and Wilmington (Delaware) have remained active in the trade and not seen major changes in their market share. The result is that the overall trade in automobile imports has not become more concentrated despite the aggregate decline in import volume.

Table 2 confirms this assertion for a variety of concentration measures. The number of ports with large shares (more than $5 \%$ or $10 \%$ shares) has actually decreased. Similarly, the overall share of the trade accounted for by the top three, five or ten ports in the trade has remained stable or perhaps even declined. At an interport (or interregional) and sector-wide (or not firm-specific) level we thus cannot discern much in the way of significant change in the spatial distribution of this economic activity.

There have, however, been some important changes within and between the various 'port ranges' that signal the more subtle change of mutual specialisation. The concept of a port range refers to a group of ports that share a portion of the coastline and hence are in most direct competition for cargo. The coastline of the contiguous 48 states of the US may be divided into the West and East/Gulf Coast ranges, and into six finer ranges (the Northwest, Northern and Southern California, the Gulf, and the South- and Northeast). Shifts in the import shares of the various port ranges reflect re-organisation of the logistics operations by individual firms.

Table 3 presents the share of automobile imports by origin and port range. The following trends are apparent. First, at the continental level, with falling surface transportation costs (USA 1997) there has been a shift towards landbridging, with imports from Asia increasingly unlikely to go through East Coast ports, and imports from Europe increasingly unlikely to go through West Coast ports. The West Coast share of imports has declined slightly relative to the East Coast, primarily because European importers more aggressively rationalised their West Coast port usage than Asian importers did on the East Coast. However, at least one European 
Table 3. Share of automobile imports by origin and port range.

\begin{tabular}{|c|c|c|c|c|c|c|c|c|c|}
\hline \multirow[t]{2}{*}{ US port range } & \multicolumn{3}{|c|}{ Asian assemblers } & \multicolumn{3}{|c|}{ European assemblers } & \multicolumn{3}{|c|}{ All assemblers } \\
\hline & $\begin{array}{c}1980 \\
(\%)\end{array}$ & $\begin{array}{c}1990 \\
(\%)\end{array}$ & $\begin{array}{c}2000 \\
(\%)\end{array}$ & $\begin{array}{c}1980 \\
(\%)\end{array}$ & $\begin{array}{c}1990 \\
(\%)\end{array}$ & $\begin{array}{c}2000 \\
(\%)\end{array}$ & $\begin{array}{c}1980 \\
(\%)\end{array}$ & $\begin{array}{c}1990 \\
(\%)\end{array}$ & $\begin{array}{c}2000 \\
(\%)\end{array}$ \\
\hline West Coast & 54.2 & 59.1 & 60.8 & 33.3 & 27.1 & 25.2 & 52.3 & 54.1 & 49.6 \\
\hline North West & 30.1 & 22.8 & 25.8 & 2.3 & 1.2 & 0.0 & 27.6 & 19.6 & 18.0 \\
\hline Northern California & 9.8 & 13.1 & 3.3 & 14.5 & 4.2 & 0.0 & 10.3 & 11.7 & 2.3 \\
\hline Southern California & 14.3 & 23.2 & 31.7 & 16.6 & 21.6 & 25.1 & 14.5 & 22.8 & 29.3 \\
\hline East Coast & 45.8 & 40.9 & 39.2 & 66.7 & 72.9 & 74.8 & 47.7 & 45.9 & 50.4 \\
\hline Gulf & 7.9 & 3.6 & - & 9.0 & 7.9 & 4.2 & 8.0 & 4.5 & 1.5 \\
\hline Southeast & 12.0 & 13.8 & 18.0 & 5.5 & 20.8 & 28.7 & 11.4 & 14.8 & 19.9 \\
\hline Northeast & 25.8 & 23.5 & 21.2 & 52.2 & 44.2 & 42.0 & 28.2 & 26.6 & 28.9 \\
\hline Continental US & 100 & 100 & 100 & 100 & 100 & 100 & 100 & 100 & 100 \\
\hline
\end{tabular}

Source: Author's analysis of PIERS Data for October of each year.

Notes: - indicates no vehicles; 0.0 per cent indicates a less than 0.05 per cent share. Origin refers to the nationality of the automobile assembler. 'All assemblers' includes imports by the US Big 3 (Ford, Chrysler, GM).

firm, Saab, has reversed this trend. After consolidating all its import operations in Brunswick in 1992, it then began importing through Port Hueneme in 2001 (Dunlap 1992; Lamb 2001).

Second, there have been important shifts within the shares on each coast. On the West Coast, the share of the Northern California range has declined dramatically, with only the port of Benicia handling some Asian imports in 2000. This facility is owned and operated by a private terminal operator and automobile processing firm, Amports. Amports, a whollyowned subsidiary of Associated British Ports, also operates facilities at Baltimore, Brunswick and Jacksonville. Automobile imports from Europe to the West Coast became concentrated in the Southern California ports, especially San Diego and Port Hueneme, in the period from 1980 to 1990.

On the East Coast, the southeast range has gained cargo share. In the 1980s this was because the entry point for some automobile imports from both Asia and Europe shifted from the northeast to southeast, presumably reflecting the redistribution of population and spend-power southwards. In the 1990s, the southeast ports gained at the expense of the Gulf ports. The Gulf ports have virtually ceased to be a factor in the automobile trade, except for the importation of Volkswagens assembled in Mexico and Europe through the port of Houston. In Houston, VW contracts with a local firm, Turning Basin Processors Inc. to provide a variety of processing functions. Cars from Asia are no longer imported through the Gulf ports, with firms such as Toyota and Honda distributing to these markets by rail from the Southern California ports.

The reorganisation of the distribution systems of automobile importers at a continental (or interport range) level again points to the importance of examining the differences in port usage patterns of specific firms. Most automobile manufacturers are concentrating their large import volumes in fewer ports. Table 4 presents various measures of the change in the average number of ports per automobile importer/manufacturer. Whereas in 1980, on average a firm would use four-and-half (4.41) ports for one per cent or more of its imports, by 2000 on average a firm would only use three (3.18) ports to this extent. ${ }^{4}$ The decline in the number of large volume ports per manufacturer was most intense during the 1990s.

While individual firms are concentrating their large volume import operations into fewer ports, at the same time the trade has not become more concentrated across the entire port system. This suggests that some ports are specialising in handling the automobiles of fewer firms, 
Table 4. The number of ports used per automobile manufacturer has declined.

\begin{tabular}{|c|c|c|c|c|}
\hline $\begin{array}{l}\text { Average number of ports } \\
\text { per firm handling }\end{array}$ & $\begin{array}{l}\text { October } \\
1980\end{array}$ & $\begin{array}{l}\text { October } \\
1990\end{array}$ & $\begin{array}{l}\text { October } \\
2000\end{array}$ & $\begin{array}{c}\text { Change } \\
1980-2000^{1}\end{array}$ \\
\hline $100+$ vehicles of the firm & 5.00 & 5.47 & 3.41 & $-1.59^{2}$ \\
\hline $1 \%+$ of firm imports & 4.41 & 4.59 & 3.18 & $-1.24 *^{2}$ \\
\hline $5 \%+$ of firm imports & 3.29 & 3.24 & 2.88 & -0.47 \\
\hline
\end{tabular}

Source: Author's analysis of PIERS Data for the month of October in each year. To control for entry and exit, these figures are for an unchanging group of 34 US Ports, and 17 automobile importers.

Notes: ${ }^{1}$ Paired samples $t$-test was used to determine statistical significance of changes from 1980 to 2000.

* Denotes significant at the 95 per cent level.

${ }^{2}$ Change from 1990 to 2000 is significant at the 99 per cent level.

although the statistical evidence for this assertion is not unambiguous. The Herfindahl concentration index may be used to measure the extent to which a port is specialised in handling the automobiles of one or just a few firms. The average concentration index for 17 automobile importers in 16 ports did rise from 1980 to 2000 , and the change from 1990 to 2000 was statistically significant (at the $95 \%$ level, tested using a paired sample $t$-test).

However, following Charlier (1988), an index of how specialised each port was in 1980, 1990 and 2000 with respect to 14 automobile importers was calculated. This specialisation index actually fell over the period, although the change was not statistically significant according to a paired samples $t$-test. While ports such as Long Beach, Los Angeles, Seattle, Houston and Wilmington are increasingly identified as the import port of one or two automobile firms, ports such as New York, Baltimore, Brunswick, Jacksonville and Port Hueneme maintain a more diverse client base. ${ }^{5}$

\section{MUTUAL SPECIALISATION: FIRM STRATEGIES MEET PORT POLICIES}

How are we to explain the fact that while individual firms are concentrating their import handling in fewer ports, the distribution of automobile imports overall has not become more concentrated? The significance of this question extends beyond the trade in automobiles, since several researchers studying patterns of port usage in the container trades have shown that while individual steamship lines are pursuing strategies of concentration, system-wide deconcentration persists (for example, see McCalla 1999).

The answer lies in recognising that there are important differences in the strategies of, and relationships between, the various actors involved in the trade. While all automobile importers require access to at least some terminal space to handle automobile imports, there are important variations in the ways in which individual automobile importers organise these logistics functions, and in the policy responses of port authorities to this demand for terminal space. The resulting geography arises from the intersection of particular firm strategies and port policies, and the concept of mutual specialisation attempts to describe the selective nature of this process.

At a minimum, an automobile importer requires on-terminal 'surge space' during discharge operations, and space to handle inspections and customs clearance. However, depending on how the onward distribution of imports is organised, the importer may also require space on or near the terminal for additional processing operations, such as fitting accessories, modifying vehicles for the local market, storage, minor repairs, quality inspections, and so on. Furthermore, an automobile importer may conduct these activities in-house or contract with a third party to provide these services.

When the automobile importer conducts processing in-house, they are drawn into direct contractual relationships with local port authorities over terminal leases. This is the case for importers such as Toyota and Nissan (through its subsidiary, DAS) that operate port facilities as key nodes in their overall distribution systems. 
Table 5. Port usage for selected automobile importers.

\begin{tabular}{|c|c|c|c|c|c|}
\hline & \multicolumn{2}{|c|}{$\begin{array}{l}\text { Number of ports } \\
\text { handling } 5 \%+\text { of } \\
\text { firm imports }\end{array}$} & \multirow[t]{2}{*}{$\begin{array}{l}\text { Ports used } \\
\text { in } 2000\end{array}$} & \multirow[t]{2}{*}{$\begin{array}{l}\text { Processor } \\
\text { (Terminal } \\
\text { Operator) }\end{array}$} & \multirow[t]{2}{*}{$\begin{array}{l}\text { Contractual } \\
\text { relationships }\end{array}$} \\
\hline & 1980 & 2000 & & & \\
\hline VW/Audi & 3 & 5 & $\begin{array}{l}\text { San Diego } \\
\text { Houston } \\
\text { Boston } \\
\text { Wilmington } \\
\\
\text { Brunswick }\end{array}$ & $\begin{array}{l}\text { Pasha } \\
\text { Turning Basin Inc } \\
\text { Boston Autoport } \\
\text { Transworld } \\
\text { Diversified } \\
\text { Services } \\
\text { International } \\
\text { Auto Processing }\end{array}$ & $\begin{array}{l}\text { VW has short-term } \\
\text { contracts with } \\
\text { processors; } \\
\text { VW leases terminal } \\
\text { from Wilmington; } \\
\text { in other ports, } \\
\text { processor } \\
\text { leases terminal }\end{array}$ \\
\hline Mercedes & 7 & 3 & $\begin{array}{l}\text { Los Angeles } \\
\text { Baltimore } \\
\text { Jacksonville }\end{array}$ & $\begin{array}{l}\text { (DAS) } \\
\text { (Premier) } \\
\text { (Amports) }\end{array}$ & $\begin{array}{l}\text { Mercedes contracts } \\
\text { with terminal } \\
\text { operators for } \\
\text { customs clearance } \\
\text { and storage only; } \\
\text { processing occurs at } \\
\text { an inland in-house } \\
\text { facility }\end{array}$ \\
\hline Toyota & 7 & 5 & $\begin{array}{l}\text { Portland } \\
\text { Long Beach } \\
\text { New York } \\
\text { Baltimore } \\
\text { Jacksonville }\end{array}$ & $\begin{array}{l}\text { Toyota } \\
\text { Motor Sales } \\
\text { SE Toyota }\end{array}$ & $\begin{array}{l}\text { Toyota has long- } \\
\text { term terminal leases } \\
\text { with port authority } \\
\text { and conducts } \\
\text { processing in-house }\end{array}$ \\
\hline Honda & 7 & 2 & $\begin{array}{l}\text { San Diego } \\
\text { Portland }\end{array}$ & $\begin{array}{l}\text { Pasha } \\
\text { Auto } \\
\text { Warehousing } \\
\text { Company }\end{array}$ & $\begin{array}{l}\text { Honda has short- } \\
\text { term contracts with } \\
\text { processors. Pasha } \\
\text { leases San Diego } \\
\text { terminal facility; in } \\
\text { Portland, Honda } \\
\text { holds terminal } \\
\text { facility lease }\end{array}$ \\
\hline
\end{tabular}

Source: Author's analysis of PIERS Data for October of each year; interviews and on-line research.

Since 1980, importers that lease port terminals to conduct in-house processing activities have been less aggressive in rationalising the number of ports they use. Other importers, such as Honda choose to contract with outside parties for port processing operations. These outside parties of course have their own goals; they may be one of the many independent port processing firms that actively compete for business from multiple automobile importers, or they may be a subsidiary of one of the steamship lines that have started offering processing services as a way of attracting cargo.
Table 5 indicates the number of ports used by selected automobile firms. It shows that the rationalisation process has been highly uneven. For example, while VW has actually increased the number of ports handling a large proportion of its imports, Mercedes has not. Since 1990, VW has expanded its usage of port facilities to include a post-production check, a measure designed to improve product quality. Although these processing activities have been contracted to independent processing firms, VW engineers are always present at the port of entry. In contrast, Mercedes has, since the early 
1990s, conducted processing operations at facilities inland from the port of entry. At three ports of entry, Mercedes contracts with an independent terminal operating and processing firm to provide the minimum customs clearance and storage functions only.

The contrast between Toyota and Honda is especially stark. In 2000 only two West Coast ports (San Diego and Portland) handled five per cent or more of Honda's imports, down from seven ports (on both coasts) in 1980. In 1980 , seven ports also handled five per cent or more of Toyota imports, but this had only been reduced to five per cent by 2000 . The explanation for the differences lies in the approach of each firm to port processing operations.

Honda typically conducts only the minimum processing at the port of entry. Furthermore, Honda's processing operations are conducted by independent processors, thus placing the firm in an indirect relationship with the port authority. In contrast, Toyota port processing facilities remain important nodes within the entire distribution system of the firm. For this reason, Toyota has been willing to sign longterm leases of up to 20 years with port authorities, in order to secure access to terminal space. Hall (2004) argues that there is a pathdependency to this organisational structure; in addition to the long-term contractual obligations, Toyota managers in these port locations have resisted the aggressive rationalisation and closure of facilities.

As with the observed variation in usage of ports among automobile firms, there are also important differences in responses of ports to the demand for terminal space by automobile importers or their agents (the independent processing firms). For example, the Port of Long Beach handled five per cent or more of the imports of six firms in 1980, but by 2000 it handled five per cent or more of the imports of only one firm, Toyota. In contrast, the Port of New York handled five per cent of more of the imports of nine firms in 1980, and by 2000 this had only declined to eight firms. ${ }^{6}$ The fact that these ports are similar in many other respects suggests that mutual specialisation is a highly uneven process and selective process.

It is no accident that most automobile importers were displaced from the Port of Long Beach; the port has since the late 1970s experienced dramatic growth in containerised cargo, and intense pressures on land for terminal space. It is also no accident that it was Toyota that remained behind when the others had departed; the port has implemented a terminal leasing policy that requires long-term dedicated terminal leases. This favoured a firm such as Toyota that was willing to meet such contractual requirements. In contrast, processing activities for automobile importers using the Port of New York are conducted by in-house processors leasing dedicated facilities from the port and by independent port processing firms with their own contractual relationship to the port authority.

\section{DISCUSSION}

This paper has used descriptive statistics on the patterns of port usage by automobile importers to the United States since 1980 to highlight a shortcoming in the way in which freight logistics flows are typically studied. The data indicate that while the overall level of concentration in the automobile import system has changed relatively little, shippers, the automobile assemblers that own the cargo, are concentrating their high-volume imports in fewer ports. These firm-specific actions intersect with port policies, such as the approach to terminal leasing, to produce the pattern of mutual specialisation. This differential and selective process can only be understood through an approach to freight logistics that takes account of the strategic actions of shippers, port authorities, carriers and other actors, and their relationships with each other. Examples of port usage by individual automobile importers showed that firmspecific factors, specifically differences in the way in which port processing operations are organised and in which access terminal space is secured, are a key factor in explaining the resulting geography.

What makes mutual specialisation so interesting in the global-local debate in economic geography is that it suggests a convergence between specific ports and specific firms, rather than a more general convergence between regions and sectors. This evidence is consistent with the notion that the usage of a port by a particular firm depends, in part, on the ability of that firm to secure and sustain appropriate institutionalised 
relationships with the port authority, and other port users and transportation service providers. A more general convergence would have implied that actor-blind factors could provide a sufficient account of the resulting geography.

The argument and evidence presented here builds on the growing recognition in the literature of the importance of firm strategy in the securing of terminal space in the evolution of seaport-systems. This debate has, for obvious reasons, been dominated by the trade in containerised cargo. For example, in a recent paper, Slack and Wang (2002) specifically addressed one aspect of the process of concentration, deconcentration and specialisation in port systems that have occupied much of the geographic literature on seaports in the containerisation era. Through case studies, they trace the rise of peripheral ports that are challenging the dominance of the major Asian ports of Hong Kong, Singapore and Shanghai. The ongoing process of creative destruction they describe is consistent with the predictions of the earlier models of change within seaport systems advanced by Bird (1971), Hayuth (1981) and others.

However, Slack \& Wang (2002) showed that the port-level causal factors driving these earlier predictions, chiefly technological change and congestion, are no longer adequate. Instead, they show how port competition is increasingly driven by the desire of steamship lines to secure terminal space; they argue that 'the roles of port authorities and terminal operators, and their relationships with the steamship lines, are at the heart of the deconcentration process' (Slack \& Wang, p. 164). Slack and Wang's argument finds support in the work of Notteboom (2002), who argued that we need to pay close attention to the way in which institutions such as terminal leasing rules act as barriers to both entry and exit within port systems. More generally, this work also calls upon us to pay closer attention to the particular actors involved in the shipping trade, and to the way in which their individual strategic actions are central to the creation of the resultant geography (see Slack et al. 1996; Guy, 2003).

It is true that the trade in automobiles is unlike the trade in containerised cargoes in the sense that the shippers are more actively involved in port selection and in managing port operations; the automobile assembler or its subsidiary may act as terminal operator and be the direct holder of a port terminal lease. This is also often the case for non-containerised bulk cargoes, but may not apply to containerised cargoes. However, instead of diminishing the argument for more research on actors, their strategies and relationships, this observation calls for attention to a different set of actors and relationships. Specifically, in the container trades, analysis of data on the shipments of individual mass retailers and in-depth research on how these actors influence ship scheduling and routeing is a crucial gap in our understanding of the patterns of port usage and the geography of logistics.

Port authorities, cargo owners and the carriers of cargo do not confront the global transportation network sui generis. Instead they are the active participants in its construction. Freight studies that emphasise only the global dimensions of the transportation system, network connections and the decisions of carriers, miss the subtle but important variations in firm and port authority relationships and strategy that underpin the actual patterns of geographic concentration, dispersal and mutual specialisation.

\section{Notes}

1. Source: Bureau of the Census, Metropolitan Area Rankings by Population Size and Percent Change for 7-1-98 to 7-1-99 and 4-1-90 to 7-199 (http://eire.census.gov/popest/archives/metro/ ma99-04.txt)

2. Likewise, Hoegh-Ugland Autoliners (HUAL) recently purchased the Wilmington DE-based Autoport, a family-owned processing firm that specialises in the preparation of automobile exports.

3. The monthly statistics presented here show Baltimore's share of the automobile trade declining dramatically from October 1990 to October 2000. This reflects a limitation of the data account (i.e. monthly statistics are subject to variation) rather than a real change in Baltimore's market share.

4. In order to control for entry, exit and mergers, these averages are calculated for a group of 17 automobile importers active and separately identifiable in the months of October 1980, 1990 and 2000.

5. Anecdotal evidence suggests that the pattern of ports becoming associated with one or a few manufacturers may already have developed in 
Europe. Nils Lie, a WWL manager is quoted in the trade magazine, Automotive Logistics (2000) thus; 'Bremerhaven is the BMW and Mercedes port, while Zeebrugge is already used by numerous manufacturers. Emden is the export port for VW. Ford, meanwhile is using both Bremerhaven and Zeebrugge.'

6. The differences between the Ports of Long Beach and New York are not explained by the fact that Long Beach and its neighbour, the Port of Los Angeles may be regarded as forming one port complex. The Port of Los Angeles handled five per cent or more of the automobiles of five firms in 1980, but by 2000 it handled five per cent or more of the imports of only two firms, namely Nissan and Mercedes. Thus the number of automobile manufacturers routeing five per cent or more of their imports through the Southern California port complex has declined from 11 per cent to three per cent, whereas in the Port of New York it has only declined from nine to eight firms.

\section{Acknowledgements}

The research was funded by grants from the National Science Foundation (DDRI Grant BCS-0000225) and the University of California Transportation Center. An earlier version of this paper was presented at the 99th annual conference of the Association of American Geographers in New Orleans. The author would like to thank Brian Slack for his especially helpful comments on an earlier draft of the paper, as well as the anonymous reviewers for their helpful comments. Any errors or omissions are the sole responsibility of the author.

\section{REFERENCES}

Automotive Logistics (2000), Second Tier Ports in Danger from Industry Consolidation, Automotive Logistics, 3. www.automotivelogistics.co.uk/magazine, accessed 28 March 2002.

BIRD, J. (1971), Seaports and Seaport Terminals. London: Hutchinson.

Brenner, N. (1999), Globalisation as Reterritorialisation: The Re-scaling of Urban Governance in the European Union. Urban Studies, March 1999 36, pp. 431-451.

Castells, M. (1996), The Information Age: Economy, Society and Culture (Vol. I: The Rise of the Network
Society). Cambridge MA, Oxford UK: Blackwell Publishers.

Charlier, J.J. (1988), Structural Change in the Belgian Port System, 1980-1986. Maritime Policy and Management 15, pp. 315-326.

Cox, K.R. (1995), Globalisation, Competition and the Politics of Local Economic Development. Urban Studies 32, pp. 213-224.

Cox, K.R. ed. (1997), Spaces of Globalization: Reasserting the Power of the Local. New York: Guilford Press.

Dicken, P. (2003). Global Shift: Reshaping the Global Economic Map in the 21st Century. (4th edn.). New York: Guilford Press.

DunlaP, C. (1992), Saab Imports Now Flow Through GA Port Only. Journal of Commerce. January 24, 1992: 9B.

Guy, E. (2003), Shipping Line Networks and the Integration of South America Trades. Maritime Policy and Management 30, pp. 231-242.

Hall, P.V. (2002), The Institution of Infrastructure and the Development of Port-regions. Unpublished PhD dissertation, UC Berkeley.

Hall, P.V. (2004), Persistent Variation: Flexibility, Organization and Strategy in the Logistics of Importing Automobiles to the United States, 1980-1999, Environment and Planning A, 36.

Harvey, D. (1982), The Limits to Capital. New York: Oxford University Press.

Hayuth, Y. (1981), Containerisation and the Local Center Concept. Economic Geography 57, pp. 160176.

Heaver, T. (1995), The Implications of Increased Competition among Ports for Port Policy and Management. Maritime Policy and Management 22, pp. 125-133.

LAMB, J.J. (2001), Hueneme's Growth is a Balancing Act. American Journal of Transportation, June 11, 2001, p. 6A.

Lipietz, A. (1993), The Local and the Global: Regional Individuality or Inter-Regionalism? Transactions of the Institute of British Geographers 18, pp. 6-18.

McCalla, R.J. (1999), From St. John's to Miami: Containerisation at Eastern Seaboard Ports. GeoJournal 48, pp. 21-28.

Noтteвоoм, T. (2002), Consolidation and Contestability in the European Container Handling Industry. Maritime Policy and Management 29, pp. 257-269.

Olson, D.J. (1992), Governance of US Public Ports: A Preliminary Survey of Key Issues. Paper prepared 
for the Marine Port Governance Roundtable, November 10, 1992. Washington: DC.

Ross, J.R. (1992), Heat is On for Cool Auto Business, Global Trade, February 1992, pp. 46-50.

Sherman, R. (2002), Seaport Governance in the United States and Canada. American Association of Port Authorities (http://www.aapa-ports.org/pdf/ governance_uscan.PDF accessed 24 September 2002).

Slack, B. (1993), Pawns in the Game: Ports in a Global Transportation System. Growth and Change 24, pp. 379-88.

Slack, B. \& Wang, J.J. (2002), The Challenge of Peripheral Ports: an Asian Perspective. GeoJournal 56, pp. 159-166.

Slack, B., C. Сomtois \& G. Sletmo (1996), Shipping
Lines as Agents of Change in the Port Industry. Maritime Policy E Management 23, pp. 298-300.

Storper, M. (1997), The Regional World: Territorial Development in a Global Economy. New York: The Guildford Press.

Storper, M. \& R. WAlker (1989), The Capitalist Imperative: Territory, Technology and Industrial Growth. London: Basil Blackwell.

USA (US Department of Transportation, Bureau of Statistics). (1997), National Transportation Statistics. Washington, DC.

Vickerman, R. (1999), The Transport Sector, New Economic Geography and Economic Development in Peripheral Regions. In: M. Beuthe \& P. NiJkmaP eds., New Contributions to Transportation Analysis in Europe. Aldershot: Ashgate. 